\title{
Comparison of Antimicrobial Effects of Mezoneuron benthamianum, Heliotropium indicum and Flabellaria paniculata on Candida species
}

\author{
Fayemi Scott O. , Osho A. \\ Redeemer's University, College of Natural Sciences, Biological Sciences Department, Km 46, Lagos/Ibadan Expressway, PMB 3005, \\ Redemption City, Mowe, Ogun State. Nigeria
}

\begin{abstract}
Alternative medicine, also called unconventional medicine, is therapeutic practices, techniques, and beliefs that are outside the realm of mainstream Western healthcare. Antimicrobial activities, minimum inhibition concentrations (MIC) and phytochemical tests of Mezoneuron benthamianum, Heliotropium indicum and Flabellaria paniculata ethanolic plant extracts were investigated against characterized Candida albicans, Candida torulopsis, Candida krusei, Candida glabrata and Candida stellatoidea isolated from human buccal cavity. The zones of inhibition for the whole plant extract of $F$. paniculata range from $12.8 \pm 0.30 \mathrm{~mm}$ against $C$. krusei to $14.5 \pm 0.50 \mathrm{~mm}$ observed against $C$. albicans while that of $H$. indicum range between $8.6 \pm 0.50 \mathrm{~mm}$ against $C$. torulopsis to $13.4 \pm 0.50 \mathrm{~mm}$ observed against $C$. glabrata, and M. benthamiamun was from $7.8 \pm 0.60 \mathrm{~mm}$ against $C$. glabrata to $12.8 \pm 0.20 \mathrm{~mm}$ against $C$. krusei. Phytochemical tests revealed saponnins, alkaloids, anthraquinones, flavonoids and tannins in $F$. paniculata extracts, and M. benthamianum extracts is positive for saponins, anthraquinones, flavonoids and tannins. But, H. indicum contained saponins and tannins only. Between $5 \mathrm{mg} / \mathrm{ml}$ and $8 \mathrm{mg} / \mathrm{ml}$ was recorded as MIC for Candida species against $F$. paniculata. M. benthamianum recorded $6-15 \mathrm{mg} / \mathrm{ml}$ while, $H$. indicum indicated $6-8 \mathrm{mg} / \mathrm{ml}$. The highest zone of inhibition in this study was obtained in F. paniculata followed by $H$. indicum and $M$. benthamianum consecutively. The conclusion was that there is the need to further investigate and characterize individual phytochemical compounds in these plants and their anti-candidal effect determined.
\end{abstract}

Keywords Heliotropium indicum, Mezoneuron benthamianum, Flabellaria paniculata, Candida species

\section{Introduction}

Generally, diseased condition may result to irritation, discomfort, malfunction of organ or the overall breakdown of the body system of which may lead to permanent disability or death of the host. The wealth of any nation is hinged on the health of such therefore, medically sick people in any nation needs treatment. Alternative medicine is therapeutic practices, techniques, and beliefs that are outside the realm of mainstream Western healthcare. Alternative medicine emphasizes therapies that improve quality of life, prevent disease, and address conditions that conventional medicine has limited success in curing, such as chronic back pain and certain cancers ${ }^{1}$. Diseases treated by alternative medical therapies include candidiasis among others.

Candidiasis is usually an opportunistic infection that is associated with immunocompromised states such as diabetes, extensive antibiotic usage, malignancies and Human Immunodeficiency Virus (HIV) infection ${ }^{2}$. However, for over

* Corresponding author:

fayscot@yahoo.co.uk (Fayemi Scott O.)

Published online at http://journal.sapub.org/microbiology

Copyright (C) 2012 Scientific \& Academic Publishing. All Rights Reserved two decades now the incidence of Candida species has been significant and non-albicans Candida species continue to replace Candida albicans at most of the clinical sites like bloodstream infections ${ }^{3}$.

The healing potential of certain plants have been discovered long before the conception of microbes that characterize them as antimicrobials, which are still in use for the treatment of various maladies to date ${ }^{4}$. Many studies revealed that plants possess substances such as peptides, unsaturated long chain aldehydes, alkaloidal constituents, some essential oils, phenol, flavonoids, saponins and tannins which may be soluble in water, ethanol, chloroform, methanol, butanol and other solvents. The characteristics of such contained compounds may then emerge them as a potentially significant therapeutic agent against human pathogens, including bacteria, fungi and virus ${ }^{5-7}$. However, $M$. benthamianum, $H$. indicum and $F$. paniculata ${ }^{8}$ are candidate plants investigated for the treatment of candidiasis in this research.

M. benthamianum is a member of the family Caesalpinoideae. The leaves are brightly red when young and dark green when old. The stem is black with reoccurred thorn. The root is brown and hard. M. benthamianum has branched shrubs and is a woody climber of up to 8 metres in height. It can be found in waste places of deciduous secondary jungle 
and savannah forest from Senegal to Nigeria ${ }^{9}$. The plant is locally called 'amuranju' or 'jenifiran' in Yoruba land ${ }^{10} . M$. benthamianum is used in folk medicine for the treatment of dermal infections and wounds in Ghana. The herbalists show a respectful regard for this plant. The leaves are considered in Senegal to be antiseptic and used in cleaning, healing of refractory sore. Young leaves are mashed and applied on wounds and swollen parts of the body in Sierra-Leone. The root is reported to be used in Ibadan area, Nigeria as chewing stick $^{10}$.

H. indicum is a member of the family Boraginaceae. It is an annual, erect branched hairsute plant that can reach $15-50 \mathrm{~cm}$ in height. Its leaves can be opposite or alternate; base decurrent along the petiole is $3-8 \mathrm{~cm}$ long. Flowers are white with a green calyx, five stamens borne on a corolla tube; a terminal style and a four lobed ovary ${ }^{8}$. It is a common weed in waste places and settled areas; flowering all year round. It is found in Australia, thought to originate from South America and seen as a significant weed in South-East Asia. Also a crop weeds in Asia, Africa and the Caribbean. It is called the cock's comb in Gambia; the French call it herbe a verrues (i.e. plant with warts). In West Africa Ghana it is called Akan-Ashante or Akomfem Atiko. In Guinean-Bissau it is called Manding -Maninka. Datokoro Kombo in Ivory Coast and in Nigeria the efik call it edisimmon, igbo call it ilolo isi mwa-eku. The Yorubas call it agogo igun or ogbe akuko. The plant has been locally used to treat inflammatory tumours, leaf-powders applied to dermatoses, especially eczema and impetigo in children in West Africa ${ }^{11}$. In Nigeria and Ghana, the leaf infusion is applied topically to sores, stings, pimples and the sap to gumboils, clean ulcers, to the eyes for ophthalmia, and mixed with castor oil to stings and poisonous bites ${ }^{12}$. Nigerian uses the plant locally to treat umbilical hernia ${ }^{13}$.

$F$. paniculata belongs to the family malpigbiaceae. It is a climbing shrub of 3-15 meters high; the leaves are slivery under surface with white pale pink flowers ${ }^{14}$. It is an herb indigenous to the tropical Africa. The plant is found in wooded savannah riverine desert or forest subjected to flooding distributed across the region from Senegal West Cameroon and Fernanda Po, and across the Congo Basin to Uganda and Tangayika. It is known by Yoruba as 'ajidere'13. And also 'ewe aran' in different part of Yoruba land in Nigeria. Commonly called 'manding maninka Conombo' in Senegal, 'lokohebe' in Serria Leone, 'baule in Ivory Coast and in Ghana it is called 'adangme'. Leaves are used on wounds and sores in Ghana ${ }^{15}$, and in Nigeria it is used for the treatment of diarrhea and dysentery as well as the treatment of sores and wounds. In Ivory Coast the leaf sap is frequently used as amenorrhea and sometimes in ancebolic ${ }^{16}$. The lainous stem serves as ties in some Ghana hut buildings ${ }^{17}$, and the root serve as part of the ingredients used for snake immunization ${ }^{18}$.

The objective of this study is therefore to test the antimicrobial effects of $M$. benthamianum, $H$. indicum and $F$. paniculata on Candida species.

\section{Materials and Methods}

\subsection{Sample Collection and Isolation}

A total of fifty students (twenty-five males and twentyfive females 400L students of Olabisi Onabanjo University, Nigeria) were randomly sampled from the University in this research. Epstein et al. ${ }^{19}$ method was employed for Candida species isolation by plating on Sabouraud Dextrose Agar (SDA) medium. Plant were collected at Ajibode (behind University of Ibadan, Akinyele Local Government, Ibadan, Oyo state, Nigeria. Authentication was carried out at APZ Department Herbarium at the Faculty of Science, Olabisi Onabanjo University, Ago-Iwoye, Nigeria

\subsection{Characterization of Isolate}

Physiological and morphological characteristics were employed for the characterization of the Candida organisms. These include germ tube, fermentation utilization of carbon compounds $^{20}$, assimilation of organic compound as carbon source ${ }^{21}$, growth at $50 \%$ or $60 \%$ D-glucose, Diazolium blue $\mathrm{B}(\mathrm{DBB})^{20}$, Urease $^{21}$, production of extracellular starch like compounds, production of pseudomycelium formation ${ }^{22}$ and starch hydrolysis tests for targets of Candida species.

\subsection{Extraction and Determination of Phytochemical Constituents of M. Bentamianum, H. Indicum and F. Paniculata}

Alade and Irobi $^{23}$ method of extraction was employed, plant extract were then placed in the rotary evaporator at $60^{\circ} \mathrm{C}$ and active ingredients concentrated. Thereafter extracts then kept in sample bottles and refrigerated at $4^{\circ} \mathrm{C}$ prior to testing. Modified Abo et al. ${ }^{14}$ method of dilution was employed where sample plant extracts were individually prepared in dimethyl sulphur oxide (DMSO) at $200 \mathrm{mg} / \mathrm{ml}$ for use.

The following phytochemical tests were carried out on the plant extracts: flavones; tannins with Trease and Evans, ${ }^{24}$ method; anthraquinones to indicate the presence of free hydroxyl-anthraquinones and or contains anthraquinones derivatives (combined anthraquinones); phenols by employing Trease and Evans ${ }^{24}$; saponins using Walls et al. ${ }^{25,26}$ method.

\subsection{Antimicrobial Sensitivity Testing of the Plant Extract}

Taylor et al. ${ }^{27}$ method of antibiotic disc diffusion method was employed. Whatman No. 1 filter paper was carefully bored into $6 \mathrm{~mm}$ diameter, sterilized and impregnated with $20 \mu \mathrm{l}$ of $200 \mathrm{mg}$ per $\mathrm{ml}$ of the respective plant extract. Nystatin (OXOID, antibiotic susceptibility test disc) was used at the manufacturer's specification as a positive control. The discs were then placed equidistantly on the agar plates readily seeded with the test Candida species (C. albicans, $C$. torulopsis, C. stellatoidea, C. parapsilosis and C. krusei) of $1 \times 10^{6}$ concentration determined by heamocytometer. 


\subsection{Determination of Minimum Inhibition Concentration}

Minimum inhibitory concentration (MIC) was determined by incorporating various amounts $(1-256 \mathrm{mg} / \mathrm{ml})$ of reconstituted plant extract into the medium (Jennifer, 2001). The plates were incubated at $37^{\circ} \mathrm{C}$ for $24 \mathrm{hrs}$. The antimicrobial activity was determined by measurement of the inhibition zone. The experiment had three replicates, while the mean values were presented. The MIC was interpreted as the lowest concentration of the extracts that did not permit any visible growth when compared with that of the control. The Negative control was $20 \mu \mathrm{l}$ DMSO solvent. The result of inhibition of the extract was compared with standard antibiotics Nystatin $(10 \mu \mathrm{g})^{28}$.

\subsection{Statistical Analysis}

Collected data were subjected to analysis using the Statistical Analytical System (SAS) Software version 8 and Microsoft excel 2007.

Table 1. The phytochemical constituents of F. paniculata, M. benthamianum and $\mathrm{H}$. indicum

\begin{tabular}{|c|c|c|c|}
\hline $\begin{array}{c}\text { Phytochemical } \\
\text { test }\end{array}$ & $\begin{array}{c}\text { Flabellaria } \\
\text { paniculata }\end{array}$ & $\begin{array}{c}\text { Mezoneuron } \\
\text { benthamianum }\end{array}$ & $\begin{array}{c}\text { Heliotropium } \\
\text { indicum }\end{array}$ \\
\hline Saponins & ++ & + & + \\
Anthraquinones & + & + & - \\
Flavonoids & + & + & - \\
Tannins & + & + & + \\
Phenols & - & - & - \\
\hline
\end{tabular}

Key: ++ means strongly present

+ means moderately present

- means not present

\section{Results and Discussion}

\subsection{Phytochemical Constituents}

Table 1 shows that $F$. paniculata, $M$. benthamianum and $H$. indicum contain saponin but was strongly present in $F$.paniculata while moderate presence was recorded for $M$. benthaminum and $H$. indicum. Anthraquinones was moderately present in both $F$. paniculata and M. benthamianum but, absent in $H$. indicum. Flavonoids also recorded moderately present in $F$.paniculata and $M$. benthamianum but was absent in $H$. indicum (table 1). Tannins were found to be present in the extracts of the three plants in moderate quantities (table1). Phenols were conspicuously absent in the plant extracts (table1)

Effects of $M$. benthamianum, $H$. indicum and $F$. paniculata on Candida species

Flabellaria paniculata: Response of Candida species to extracts of $F$. paniculata in table 2 demonstrates inhibition zone of C. albicans, C. torulopsis, C. stellatoidea, C. glabrata and C. krusei as $14.5 \pm 0.50 \mathrm{~mm}, 13.4 \pm 0.50 \mathrm{~mm}$, $13.0 \pm 0.90 \mathrm{~mm}, 14.1 \pm 0.40 \mathrm{~mm}$ and $12.8 \pm 0.30 \mathrm{~mm}$ respectively. This result revealed that C. albicans has the highest susceptiblity to ethanolic extracts of $F$. paniculata. The results as shown in table 2 demonstrate antimicrobial activity of of $F$. paniculata extract when compared with that of the standard and commercially available drug. The inhibition zone of $14.1 \pm 0.40 \mathrm{~mm}$ recorded against $C$. glabrata by $F$. paniculata further demonstrate this activity especially when compared with $12.0 \pm 0.90$ recorded for the standard drug Nystatin.

Heliotropium indicum: Responses of C. albicans, C. torulopsis, C. stellatoidea, C. glabrata and C. krusei records $9.3 \pm 0.50 \mathrm{~mm}, 8.6 \pm 0.50 \mathrm{~mm}, 11.3 \pm 0.20 \mathrm{~mm}, 13.4 \pm 0.50$ $\mathrm{mm}$ and $12.4 \pm 0.50 \mathrm{~mm}$ respectively. This indicates that extracts of $H$. indicum may not possess the strength of antifungal property displayed by $F$. paniculata as indicated in table 2. The results also showed the extracts antimicrobial activity of the extract of $H$. indicum when compared with that of the standard and commercially available drug. The inhibition zone of $13.4 \pm 0.50 \mathrm{~mm}$ recorded against $C$. glabrata by $H$. indicum further demonstrate this activity especially when compared with $12.0 \pm 0.90$ recorded for the standard drug Nystatin.

\subsection{Minimum Inhibitory Concentration}

The results obtained by the minimum inhibition concentration (MIC) studies of $F$. paniculata on Candida species records $5-8 \mathrm{mg} / \mathrm{ml}$. Thus MIC indicated on C. albicans and $C$. glabrata records $5 \mathrm{mg} / \mathrm{ml}$, C. stellatoidea and C. torulopsis records $8 \mathrm{mg} / \mathrm{ml}$, and C. krusei records $7 \mathrm{mg} / \mathrm{ml}$.

MIC studies on M. benthamianum revealed $5-15 \mathrm{mg} / \mathrm{ml}$. This study indicates $8 \mathrm{mg} / \mathrm{ml}$ for C. albicans and C. stellatoidea, $15 \mathrm{mg} / \mathrm{ml}$ for C. krusei, $6 \mathrm{mg} / \mathrm{ml}$ for C. torulopsis and $5 \mathrm{mg} / \mathrm{ml}$ for C. glabrata. H. indicum records $6-8 \mathrm{mg} / \mathrm{ml} \mathrm{MIC}$ against the studies Candida species. Thus, $C$. stellatoidea and $C$. glabrata indicated $8 \mathrm{mg} / \mathrm{ml}$ while $C$. albicans and $C$. torulopsis records $6 \mathrm{mg} / \mathrm{ml}$ and C. krusei records $7 \mathrm{mg} / \mathrm{ml}$.

Table 2. Effects of M. benthamianum, H. indicum and F. paniculata on Candida species

\begin{tabular}{|c|c|c|c|c|c|}
\hline \multirow[b]{2}{*}{ Candida species } & \multicolumn{5}{|c|}{ Inhibition Zones (mm) } \\
\hline & $\begin{array}{l}\text { Flabellaria paniculata } \\
\qquad(200 \mathrm{mg} / \mathrm{ml})\end{array}$ & $\begin{array}{l}\text { Heliotropium indicum. } \\
\qquad(200 \mathrm{mg} / \mathrm{ml})\end{array}$ & $\begin{array}{l}\text { Mezoneuron benthamianum } \\
(200 \mathrm{mg} / \mathrm{ml})\end{array}$ & Control (DMSO) & $\begin{array}{c}\text { Control (Nystatin) } \\
(10 \mu \mathrm{g} / \mathrm{ml}) \\
\end{array}$ \\
\hline C.albicans & $14.5 \pm 0.50$ & $9.3 \pm 0.50$ & $8.7 \pm 0.20$ & $6.0 \pm 0.00$ & $17.0 \pm 0.90$ \\
\hline C.torulopsis & $13.4 \pm 0.50$ & $8.6 \pm 0.50$ & $8.5 \pm 0.40$ & $6.0 \pm 0.00$ & $16.0 \pm 0.90$ \\
\hline C.Stellatoidea & $13.0 \pm 0.90$ & $11.3 \pm 0.20$ & $8.3 \pm 0.50$ & $6.0 \pm 0.00$ & $17.0 \pm 0.90$ \\
\hline C.glabrata & $14.1 \pm 0.40$ & $13.4 \pm 0.50$ & $7.8 \pm 0.60$ & $6.0 \pm 0.00$ & $12.0 \pm 0.90$ \\
\hline C. krusei & $12.8 \pm 0.30$ & $12.4 \pm 0.50$ & $12.8 \pm 0.20$ & $6.0 \pm 0.00$ & $17.0 \pm 0.90$ \\
\hline
\end{tabular}


The presence of saponin and tannins in the ethanolic extracts of Heliotropium indicum supports the earlier report of Akinlolu et al $^{29}$. However, observation in this study further revealed the presence of alkaloids in the aqueous extract of Heliotropium indicum. The antimicrobial activity observed may be attributed to these phytochemicals. This is fully corroborated by Adelaja et al. ${ }^{30}$ who reported the histogastroprotective property of this plant extract on laboratory winster rats and linked the observed results to the presence of saponins, tannis and alkaloids in Heliotropium indicum. Also the antimicrobial activity of $M$. benthaminum was found to be high in this study, which was similar to the report made by Dickson et al. ${ }^{31}$ who reported that the antimicrobial activity of the ethanol extract of $M$. benthaminum was better than that of the petroleum spirit extract and chloroform extract of the plant.

The anticandidal properties of $M$. benthamianum may be due to the presence of saponins, anthracquinones, flavonoids and tannins and the best anticandidal performance displayed by $F$. paniculata extracts among the three plant extracts may be due to the strong saponins indicated in this study. Hence, in $H$. indicum phytochemical analysis, anthracquinones and flavonoids are absent.

The antimicrobial activity of ethanolic extracts of $M$. benthamianum is more effective in this study than that of petroleum spirit and chloroform extracts reported by Dickson $e t a l .{ }^{31}$ and in line with this assertion, the ethanolic extract contained saponins, anthraquinones, flavonoids and tannins of which may be responsible for the anticandidal activity observed in the plant.

The minimum inhibition concentration values obtained for the $F$. paniculata plants extract indicates that there is a need for further purification when compared to the values obtained from similar work done by Akinlolu et al. ${ }^{29}$ where he obtained for $S$. aureus $(2 \mathrm{mg} / \mathrm{ml})$ and $P$. aeruginosa $(1.75$ $\mathrm{mg} / \mathrm{mI}$ ) from a purified extract.

The broad spectrum nature of $F$. paniculata anticandida activity on Candida species is in this study may be attributed to the strong presence of saponins in addition to other phytochemicals contained in the ethanolic extracts of the plant. This is also found in Abo and Olugbuyiro ${ }^{14}$ studies on bacterial isolates treatment of the plant.

\section{Discussion}

The presence of saponin and tannins in the ethanolic extracts of Heliotropium indicum supports the earlier report of Akinlolu et al. (2008). However, observation in this study further revealed the presence of alkaloids in the aqueous extract of Heliotropium indicum. The antimicrobial activity observed may be attributed to these phytochemicals. This is fully corroborated by Adelaja et al. (2008) who reported the histo-gastroprotective property of this plant extract on laboratory winster rats and linked the observed results to the presence of saponins, tannis and alkaloids in Heliotropium indicum. Also the antimicrobial activity of $M$. benthaminum was found to be high in this study, which was similar to the report made by Dickson et al. (2006) who reported that the antimicrobial activity of the ethanol extract of $M$. benthaminum was better than that of the petroleum spirit extract and chloroform extract of the plant. The anticandidal properties of $M$. benthamianum may be due to the presence of saponins, anthracquinones, flavonoids and tannins and the best anticandidal performance displayed by $F$. paniculata extracts among the three plant extracts may be due to the strong saponins indicated in this study. Hence, in H. indicum phytochemical analysis, anthracquinones and flavonoids are absent.

The antimicrobial activity of ethanolic extracts of $M$. benthamianum is more effective in this study than that of petroleum spirit and chloroform extracts reported by Dickson et al. (2006) and in line with this assertion, the ethanolic extract contained saponins, anthraquinones, flavonoids and tannins of which may be responsible for the anticandidal activity observed in the plant.

The minimum inhibition concentration values obtained for the $F$. paniculata plants extract indicates that there is a need for further purification when compared to the values obtained from similar work done by Akinlolu et. al. (2006) where he obtained for $S$. aureus $(2 \mathrm{mg} / \mathrm{ml})$ and $P$. aeruginosa $(1.75 \mathrm{mg} / \mathrm{mI})$ from a purified extract.

The broad spectrum nature of $F$. paniculata anticandida activity on Candida species is in this study may be attributed to the strong presence of saponins in addition to other phytochemicals contained in the ethanolic extracts of the plant. This is also found in Abo and Olugbuyiro, (2004) studies on bacterial isolates treatment of the plant.

Table 3. Minimum Inhibition of M. benthamianum, H. indicum and F. paniculata on Candida species

\begin{tabular}{|c|c|c|c|c|c|}
\hline & C.albicans & C.torulopsis & C.stellatoidea & C.glabrata & C. krusei \\
\hline F. paniculata $(20 \mu 1$ of crude extract inhibition zone) & $9.0 \pm 1.00$ & $6.0 \pm 0.5$ & $7.0 \pm 0.00$ & $7.0 \pm 1.2$ & $7.0 \pm 1.8$ \\
\hline MIC (mg/ml) & 5 & 8 & 8 & 5 & 7 \\
\hline M.benthamianum $(20 \mu 1$ of crude extract inhibition zone) & $9.0 \pm 0.60$ & $7.0 \pm 1.00$ & $8.0 \pm 1.20$ & $8.0 \pm 0.60$ & $6.0 \pm 0.60$ \\
\hline MIC (mg/ml) & 8 & 6 & 8 & 5 & 15 \\
\hline H. indicum $(20 \mu 1$ of crude extract inhibition zone) & $8.0 \pm 1.5$ & $7.0 \pm 0.60$ & $7.0 \pm 1.00$ & $9.0 \pm 0.60$ & $7.0 \pm 0.60$ \\
\hline MIC (mg/ml) & 6 & 6 & 8 & 8 & 7 \\
\hline DMSO (control) $20 \mu 1$ & na & na & na & na & na \\
\hline Nystatin (control) $20 \mu l$ of $10 \mu \mathrm{g} / \mathrm{ml}$ & $17 \pm 0.90$ & $16 \pm 0.90$ & $17 \pm 0.90$ & $12 \pm 0.90$ & $17 \pm 0.90$ \\
\hline
\end{tabular}

Key: MIC $=$ Minimum Inhibition Concentration na $=$ not applicable 


\section{Conclusions}

In this study, although all the three screened plants exhibits anticandidal activity but, $F$. paniculata appears to have broad anticandidal spectrum than $M$. benthamianum and $H$. indicum. There is need for more work to be done on the extraction of each phytochemical candidate and their respective antimicrobial or anticandidal studies on the studied plants.

The authors hereby declare that there is no conflict of interest between the authors of this research paper.

Ethical approval is not required for this research work.

\section{ACKNOWLEDGEMENTS}

The authors hereby acknowledged the use of Biology laboratory at Redeemer's University, RCCG camp, Ogun State, Nigeria.

\section{REFERENCES}

[1] Owolabi J, Omogbai EKI, Obasuyi O. Antifungal and antibacterial activities of the ethanolic and aqueous extract of Kigelia africana (Bignoniaceae) stem bark. Afr. J. Biotechnol. 2007; 6 (14): 882-85

[2] Vaishali Wabale, Anju Kagal, Renu Bharadwaj. Bombay Hospital Journal. 2008; 2:50

[3] Chander J. A textbook of Medical Mycology. 2nd ed. 2002; 212-227

[4] Doughari JH, El-mahmood AM. Tyoyina. Antimicrobial activity of leaf extracts of Senna obtusifolia (L). African Journal of Pharmacy and Pharmacology. March 2008; $2(1) 7-13$

[5] El astal ZY, Aera A, Aam A. Antimicrobial activity of some medicinal plant extracts in Palestine. Pak. J. Med. Sci. 2005; 21(2):187

[6] Bratman Steven. The Alternative Medicine Source book: A Realistic Evaluation of Alternative Healing Methods. Lowell House. 1999

[7] Odebiyi, O. O, Sofowora EA. Phytochemical screening of Nigerian medicial plants II. Lloydia. 1978; 41: 234

[8] Odugbemi Tinuola O, Odugbemi Babatunde. Economic Benefit of Medicinal Plants. A Textbook of Medicinal Plants from Nigeria. 2008; Ed. Odugbemi, T. University of Lagos Press. P. 343-540

[9] Cox PA. The ecthno-botanical Approach to Drug Discovery: Strength and Limitation. 1994; ed Prance G. T. p. 25-40

[10] Verger P. Awon ewe Osanyin (Yoruba Medicinal Leaves). University of Ife. 1997. P. 1-55

[11] Dawodu K. Folklore Healing in Africa, Journal of Ethnobiology and Ethnomedicine. 1964. P. 726-734

[12] Adegoke AL. West African plants folkore research. Journal of ethnophamacology. 1968; 5:145-150

[13] Burkill HM. The useful Plants of West Tropical Africa. 1995; 3 (2). Royal Botanical gardens, Kew P. 3

[14] Abo KA, Olugbiyiro JA0. Phytochemical And Antibacterial Studies of Extracts of Flabellaria paniculata. African Journal of Biomedical Research 2004; 7: 36

[15] Daziel JM. The useful Plants of West Tropical Africa, London, Grown agent for the colonies. 1937

[16] Debray A. Useful Plants of West Tropical Africa, 1st ed. Pp 134

[17] Abbiw DK. Useful plants of Ghana - West African use of wild and cultivated plants. Intermediate Technology Publications and the Royal Botanic Gardens Kew. 1990. ISBN No. 1-85339-043-7 or 1-85339-080-1 Hardback

[18] Ampofo Oku. First Aid in Plant Medicine, Gbana Royal Reconstruct Movement Viampong Akwapim. 1993. Waterville Publishing House, Accra, Ghana. P. 27-30

[19] Epstein JB, Kimura IH, Menard TW, Truelove EL, Pearsall N. Effect of specific antibodies on the interaction between the fungus Candida albicans and human oral mucosa. Arch. Oral Biol. 1982; 27: 469 -474

[20] Beech FW, Davenport, RR, Goswell KW, Burnett JK. Two Simplified Schemes for Identifying yeast cultures. Identification methods for Microbiologists Part II. 1968. Ends. Gibbs BM and Shapton DA. Academic Press London. p. 152-175

[21] Barnett JA, Payne RW, Yarrow D. Yeasts: Characteristics and classification. 1983. Cambridge: Cambridge University Press. 83-85

[22] Ethiraj S, On-kara H, Suresh ER. A note on the Nature and Sequence of Yeasts during Fermentation of Apples grown in India. Journal of Applied Bacteriology 1980; 48: 97-100

[23] Alade PI, Irobi ON. Antimicrobial activities of crude leaf extracts of Acalypha wilkesiana. J. Ethphamarcology, 39; 3: $171-174$

[24] Trease GE and Evans WC. Phamarcognosy. 1989. 13th edn., Bailliere Tindale Ltd., London

[25] Wall ME, Edy CR, McClenna ML and Klump ME. Detection and estimation of steroid sapogenins in plant tissue. Anal. Chem. 1952; 24: 1337

[26] Wall ME, Krider MM, Krewson CF, Edddy CR, Wilaman JJ, Cordel DS and Gentry HS. Steroidal sapogenins XIII. Supplimentary table of data for steroidal sapogenins VII. Agr. Research Service Circ. 1954; 363; 17

[27] Taylor RSL, Edel F, Manandhar PN, Towers GHN. Antimicrobial activities of southern Nepalese medicinal plants. J. of Ethnophamarcology. 1996; 50: 97 - 102

[28] Osho A, Adetunji T. Antimicrobial Activity of The Essential Oil of Ageratum conyzoides L. Asian Journal of Science and Technology. 2011;2(3): 1-5

[29] Akinlolu Abdulazeez A, Sadiq Moriam O, Ayoola M. D, Otulana J. O, Abimbola Olayiwola, A. B. Ejiwunmi. Morphological Gastroprotective Effects of Heliotropium indicum on Gastric Ulcerated MucosaI. Pak J Pathol. 2006; 17(2): 60-64 
[30] Adelaja AA, Ayoola MD, Otulana JO, Akinola OB, Olayiwola AA, Ejiwumi AB. Evaluation of the Histo- Gastroprotective and Antimicrobial Activities of Heliotropium Indicum Linn (Boraginaceae). Malaysian J. Med. Sci. 2008; 15(3): $22-30$
[31] Dickson RA, Houghton PJ, Hylands PJ, Gibbons S. Antimicrobial, resistance-modifying effects, antioxidant and free radical scavenging activities of Mezoneuron benthamianum Baill., Securinega virosa Roxb. \&Wlld. and Microglossa pyrifolia Lam. Phytotherapy Research. 2006; 20(1): 41-5 